\title{
Student Worksheet Based on Wayang for Elementary School
}

\section{Eva Amalia ${ }^{1}$, Harun Rasyid ${ }^{1}$, and Unik Ambarwati ${ }^{2}$ \\ ${ }^{1}$ Department of Primary Education,Graduate School, Yogyakarta State University \\ ${ }^{2}$ Department of Elementary School Teacher Education, Yogyakarta State University}

\section{Abstract}

Wayang is one of the main culture in Indonesia. According to UNESCO, wayang is masterpiece of oral and intangible heritage of humanity. Unfortunately, wayang is lack of preservation. This study is intended to develop student worksheet based on wayang for elementary school. Developing student worksheet based on wayang in elementary school is a new potential way for preservation. The aim of this research is to know feasibility of student worksheet based on wayang. This research design modified from development model of Borg and Gall, which was done in the ten steps of research. The result of this research: Score of material expert is 4.16 (Good), score of media expert is 4.28 (Very good), score of preliminary testing field is 4.45 (Very Good), score of main field testing is 4.46 (Very good), and operational field testing score is 4.32 (Very Good). After all step have been finished, development of student worksheet based on wayang is valid for instruction

\section{Keywords: Student Worksheet; Character of Wayang}

Received: 2 May 2019

Accepted: 19 June 2019

Published: 3 July 2019

Publishing services provided by Knowledge E

(c) Eva Amalia et al. This article is distributed under the terms of the Creative Commons

Attribution License, which permits unrestricted use and redistribution provided that the original author and source are credited.

Selection and Peer-review under the responsibility of the ICMEd Conference Committee.

\section{Introduction}

Wayang is one of the main culture in Indonesia. According to UNESCO on November 7, 2003, wayang is masterpiece of oral and intangible heritage of humanity(2).Wayang is traditional literature that contains moral story. The moral story contained in wayang is a symbol of life that can be used to shape the identity of Indonesian country.It means wayang must be preserved by Indonesian people. In fact, wayang is lack of preservation. According to tourism statistic data, the visitors of Wayang Sasono Hinggil is decline from 2009 to 2012

TABLE 1: Tourism Statistic Data.

\begin{tabular}{|l|l|l|l|l|l|}
\hline Visitors of Wayang Sasono Hinggil & 2008 & 2009 & 2010 & 2011 & 2012 \\
\hline
\end{tabular}

Another facts show that people's interest in wayang is actually diminishing. According to tourism statistics in 2015 the Kakayon Puppet Museum only gets around 2914 visitors 
a year. This number is different with visitors of other museums, which on average reach more than 6,000 visitors a year [15]. The globalization era also gives bad influence on wayang. Especially free entry of foreign culture, increasingly erodes people's love of wayang. Finally, local culture such as wayang is increasingly marginalized.Based on the fact, goverment is preserving wayang through education. In elementary school wayang have been taught in Javanese language learning. In curriculum wayang pictures are also found in several thematic book for students [1]. Unfortunately, this effort has not succeeded because material learning in Javanese language not only wayang but also aksara graphic, linguistic and so on. Time alocation is not enough for teaching wayang. Furthermore, based on observations and interviews conducted in July-September 2016 at Golo State Elementary School, students are less concerned about wayang. In libraries, no student borrow books about wayang. Most students know heroes from abroad such as Superman, Batman, Ultraman but they are not familiar with heroes from wayang story.

Therefore, Indonesia need another strategy to increase students' interest in wayang because wayang is one of the national identities that must be preserved. One of potential way is combining wayang with student worksheet. Student worksheet is a teaching material that is familiar to students. Student worksheet will be detect students' comprehension about wayang. For this reason, it is necessary to develop student worksheet based on wayang. This student worksheet based on wayang will be teach out of Javanesse learning. So, student can learn wayang everyday not only in Javanese language but also in another subject learning.

\section{Literature Review}

This study has related work with Puspita S (2015). Puspita S (2015) develop thematic material worksheet for fourth grade elementary school. [16]. Puspita S (2015) developed type of work. However, this study develop student worksheet based on wayang. Cohen, M. I. (2018) stated that wayang is form of art from Indonesia [5]. Wayang have relationship with education and media. Maretta, Y. (2016) stated that teacher can make integration between local wisdom and teaching science [6]. It means conducted wayang in education especially in student worksheet are can be reality. Teacher have potential way for combining wayang with material learning such as student worksheet. Wayang is a type of local wisdom (Wibawa, 2017: 1) [7]. Wayang is an indigenous Indonesian culture that has been recognized by UNESCO [2]. Wayang figures used in student worksheet are Puntadewa, Janaka, Werkudara, Nakula, Sadewa, Anoman, Rama, Prabu 
Kresna, Kumbakarna, Gathotkaca, Semar, Gareng, Petruk Bagong. They have many good characters.

Student worksheet is one of the printed teaching materials consisting of assignments in the form of instructions and steps designed to increase student involvement or activities in the teaching and learning process [1]. Student worksheet has 6 main elements, namely: title, study guide, basic competencies / subject matter, supporting information, assignments or work steps, and assessment. According to Darmojo (1993) student worksheet must contain various requirements such as didactic requirements, construction requirements, and technical requirements. Student worksheet based on local wisdom can make students know, realize, care, and take implementation local values into appropriate daily behavior with norms considering local community [8].

\section{Material \& Methodology}

This research is a R\& D (Research and Development). The model used is Borg \& Gall model [13]. This model has the following ten development stages: 1) Research and information collecting; 2) Planning; 3) Initial product development; 4) Initial field trial; 5) Revision of main products; 6) Main field trials; 7) Revision of operational products; 8) Operational field trials, 9) Revision of the final product; 10) Dissemination and implementation. Subjects were students and teachers of Golo Elementary School, Umbulharjo, Yogyakarta. Data collection techniques were through interviews, observation, product appraisal by experts, and student response questionnaires. The analysis technique uses qualitative and quantitative data analysis. Qualitative data is in the form of criticism and suggestions from material experts, media experts, and students who are then analyzed and described qualitatively to revise the product. Quantitative data is based on assessment scores of students, material experts, media experts from instrument questioner. The score is calculated by the formula to be changed to scale Very Good, Good, Fair, Less, and Very Less.

\section{Results and Discussion}

In the need analysis stage it is done in schools to find out learning in school. All information is obtained through interviews, observations, literature reviews and analysis of teachers and student books. After performing need analysis then student worksheet design is carried out. Student worksheet are designed according to the student's book 2013 curriculum class IV theme 4 "My Heroes" Subtheme 1 "Heroism". Student 
TABLE 2: Categorization Guideline Score Product Feasibility Assessment.

$\begin{array}{lr}\text { Score Interval } & \text { Score } \\ \mathbf{R i}+\mathbf{1 , 5} \text { Sdi }<\text { score } \leq \text { quantity score maks } & 5 \\ \mathbf{R i}<\text { score } \leq \mathbf{R i}+\mathbf{1 , 5} \text { Sdi } & 4 \\ \mathbf{R i} \text { - 1,5 Sdi < skor } \leq \mathbf{R i} & 3 \\ \text { Quantity scoremin } \leq \text { score } \leq \mathbf{R i} \text { - 1,5 Sdi } & 2 \\ \leq \text { score } \leq \text { Quantity scoremin } & 1 \\ \text { that: } & \\ \text { Ri = Ideal average = } 1 / 2 \text { (score maks + score min) } & \\ \text { Sdi = Ideal deviation standart = (score maks - score min) }\end{array}$

worksheet consists of: cover, ownership identity, character recognition, preface, mapping of core competencies, study instructions, table of contents, basic competencies,wayang illustrations, wayang stories, learning activities, explanation of material, exercises, assignments, reflections, summaries, glossaries, bibliography and author profile.The next step is validation. Validation is carried out by material experts and media experts. The following are the results of the material experts:

TABLE 3: Data on the Feasibility of student worksheet by material experts (Content).

\begin{tabular}{|c|c|c|c|c|}
\hline Criteria & Aspect & SItem & Score & Category \\
\hline Content & Curriculum suitability & 3 & 4 & Good \\
\hline & Purpose suitability & 2 & 4 & Good \\
\hline & Truth content & 2 & 4 & Good \\
\hline $\begin{array}{c}\text { Compatibility of worksheets } \\
\text { with students }\end{array}$ & 2 & 4 & Good \\
\hline
\end{tabular}

TABLE 4: Data on the Feasibility of student worksheet by material experts.

\begin{tabular}{|l|c|c|c|c|}
\hline Criteria & Aspect & Eltem & Score & Category \\
\hline $\begin{array}{l}\text { Student } \\
\text { worksheet }\end{array}$ & Component & 2 & 5 & Very Good \\
\hline & Instruction & 2 & 5 & Very Good \\
\hline & $\begin{array}{c}\text { Performance } \\
\text { Compatibility content and } \\
\text { worksheet }\end{array}$ & 2 & 5 & Very Good \\
\hline
\end{tabular}

TABLE 5: Data on the Feasibility of evaluation by material experts.

\begin{tabular}{|l|c|c|c|c|}
\hline Criteria & Aspect & Iltem & Score & Category \\
\hline Evaluation & Evaluation aspect & 2 & 4 & Good \\
\hline & didactic requirements & 2 & 3 & Fair \\
\hline $\begin{array}{c}\text { construction conditions } \\
\text { Instruction }\end{array}$ & 6 & 4 & Good \\
\hline
\end{tabular}

Total score: 


Criteria
Content
Student worksheet
Evaluation
Average material expert

\begin{tabular}{|c|}
\hline Average score \\
\hline 4 \\
\hline 5 \\
\hline 4 \\
\hline 4 \\
\hline
\end{tabular}

\begin{tabular}{|l|} 
Category \\
Good \\
Very Good \\
\hline Good \\
\hline Good
\end{tabular}

Following are the results of feasibility from media experts

TABLE 6: Data on the Feasibility of media expert.

Criteria
Technical Condition
Production
Media Capability
Design
Advantages
Average

\begin{tabular}{|c|}
\hline Score \\
\hline 4 \\
\hline 4 \\
\hline 4 \\
\hline 4 \\
\hline 5 \\
\hline $21 / 5$ \\
\hline
\end{tabular}

\begin{tabular}{|c|}
\hline Category \\
\hline Good \\
Good \\
\hline Good \\
Good \\
\hline Very Good \\
\hline Very Good \\
\hline
\end{tabular}

Based on the initial field test, main field testing and operational field testing. the module was tested for 3 times. First is initial field testing with 10 subject, main field testing 30 subject, operational field testing 80 subject.

TABLE 7: Data on field testing.

Field testing
Initial field testing
Main field testing
Operational field testing
Average

\begin{tabular}{|l|}
\hline Score \\
\hline 4.43 \\
\hline 4.45 \\
\hline 4.32 \\
\hline 4.41 \\
\hline
\end{tabular}

Category
Very Good
Very Good
Very Good
Very Good

\section{Discussion}

The final product of this study is a student worksheet based on wayang. Before being valid student worksheets have already been through several revisions. Student worksheet based on wayang development have been adapted to the recent Indonesian curriculum, student characteristics, and student needs. Learning materials that are packaged in a clear storyline will make the material last longer in students' memory [3]. Thus, this is an addition to increasing students' learning motivation for wayang because of their interesting presentation

In addition, there are several things that need to be revised according to media experts, such as the use of images on student worksheet that must be clear. The images and text presented on the student worksheet must be balanced. Students learn in 
concrete operations, where students will easily learn if students see things that interest students. The use of layout and background must be adjusted to the characteristics of students. Avoid using rigid layouts for elementary school age students. The layout is rigid, more text than pictures, the images presented are not sufficiently able to explain the material, and the colorless images can become obstacles in learning [3]. Through revisions based on suggestions and input from the validator, the acquisition of superior categories shows the initial product of the learning student worksheet that is suitable for testing. This puppet character based worksheet has gone through a series of validations from experts. The final results of media validation obtained a score of 4.28 in the Very Good category. The final results of material validation obtained a score of 4.16 in the Good category. After being tested by material and media experts, student workheet is tested for fourth grade students of Golo Elementary School. In the initial testing and the main field testing the researchers did not encounter significant obstacles.

The next step is to conduct three product testing: initial field tests, main field trials, and operational field trials. Initial field trials and key field trials are conducted to determine student responses. This is also used as a consideration for the improvement of product. Meanwhile, some input from students related to the images used in the material as well as spelling and grammar. After that, the revision is made according to the suggestions from the students' responses. Based on the results of the initial field testing and the main field testing, it was found that products were said to be feasible and ready to be tested in operational field trials. The next stage was the operational field trial. Operational field trials are conducted to find out the opinions of students on broader subjects. Based on the questionnaire, this LKS received a score of 4.32 Very Good category.

This student worksheet based on wayang includes several elements including the opening, filling, and closing sections. Thematic learning requires learning that is meaningful or in accordance with the context of the student's residence. Curriculum 13 emphasizes that one of the principles is the development of an actual and contextual syllabus. In addition, learning is emphasized on characteristics, needs, and regional suitability [4]. Learning in the 2013 Curriculum emphasizes contextual learning. The lesson is adapted to the characteristics of students and socio-cultural students. Sociocultural environment can function as a source of contextual learning [14]. Learning will be more meaningful if students know and experience student learning themselves. The socio-cultural environment provides many benefits for students to develop students' abilities. The use of socio-cultural based modules can provide unlimited and diverse learning. Besides that, learning by using a socio-cultural based module facilitates the 
writing skills of students' description so that students can improve concept understanding when students integrate, organize, and clarify existing knowledge in socioculture with what will be written Based on the discussion, it can be concluded that worksheets based on wayang figures are suitable for use in the learning process. This feasibility has gone through the development research phase and has been in accordance with the needs of students in school. Wayang is one of sosiocultural. Wayang is local wisdom. Cohen, M. I. (2018) stated that wayang is form of art from Indonesia [5]. Wayang have relationship with education and media. Maretta, Y. (2016) stated that teacher can make integration between local wisdom and teaching science [6]. It means conducted wayang in education especially in student worksheet are can be reality. Teacher have potential way for combining wayang with material learning such as student worksheet. Wayang is a type of local wisdom [7]. Wayang is an indigenous Indonesian culture that has been recognized by UNESCO [2]. Wayang figures used in student worksheet are Puntadewa, Janaka, Werkudara, Nakula, Sadewa, Anoman, Rama, Prabu Kresna, Kumbakarna, Gathotkaca, Semar, Gareng, Petruk Bagong. They have many good characters.

Student worksheet is one of the printed teaching materials consisting of assignments in the form of instructions and steps designed to increase student involvement or activities in the teaching and learning process [11]. Student worksheet has 6 main elements, namely: title, study guide, basic competencies / subject matter, supporting information, assignments or work steps, and assessment. According to Darmojo (1993) student worksheet must contain various requirements such as didactic requirements, construction requirements, and technical requirements [11]. Student worksheet based on local wisdom can make students know, realize, care, and take implementation local values into appropriate daily behavior with norms considering local community [8].

\section{Conclusion}

Based on the results of the research and discussion, student worksheet based on wayang is valid for instruction This is based on the results of the study as follows. a) the assessment of the media scored 4.28 with the category "Very Good", b) an assessment of the material with a score of 4.16 in the "Good" category. c) initial field testing obtained score of 4.45 with the category "Very Good" d) main field testing received an average score of 4.46 with the category "Very Good" e) operational field testing obtained an average score of 4.32 with category "Very Good"f) average score of the field testing was 4.41 in the Very Good category. 


\section{References}

[1] Prihatini, Arti.(2015). Pengintegrasian Konten Budaya Lokal dalam Buku Tematik Pegangan Siswa Kelas V Sekolah Dasar. Lingua, 12 (2): 175-187September 2015. Universitas Negeri Malang.

[2] Byard-Jones TIM.(2001).Development in Performance Practice The Creation of New Genres and Social Transformation in Yogyakarta Wayang kulit.Taylor \& Francis Group.Vol.11. HIm 43-54

[3] Indaryati, I., \& Jailani, J. "Pengembangan media komik pembelajaran matematika meningkatkan motivasi dan prestasi belajar siswa kelas V." Jurnal Prima Edukasia, 3(1), 84-96. doi: http://dx.doi.org/10.21831/jpe.v3i1.4067, (2015).

[4] Ibrahim \& Zubainur, C. M. "Integrative curriculum in teaching science in the elementary school." Journal of Arts, Science \& Commerce. 4 (1). 48-54. (2015).

[5] Cohen, M. I. (2018). The dr. walter angst and sir henry angest collection of indonesian puppets: The structure of the conjuncture. Asian Theatre Journal: ATJ, 35(2), 300328. Retrieved from https://search.proquest.com/docview/2102831076?accountid= 31324

[6] MARETTA, Y. (2016). Preparing prospective teachers in integrating science and local wisdom through practicing open inquiry. Journal of Turkish Science Education, 13(2) Retrieved from https://search.proquest.com/docview/1824858201?accountid=31324

[7] Wibawa, Lutfi. (2017). Identification of Local Wisdom Values in the Village Bejiharjo for Youth Conflict Resolution Education.Advances in Social Science, Education and Humanities Research (ASSEHR), volume 66 1st Yogyakarta International Conference on Educational Management/Administration and Pedagogy (YICEMAP 2017): Atlantis Press.

[8] Vembriyanti, y.2017.Pengembangan LKS berbasis kearifan lokal. JOM FKIP. Riau.

[9] Soemardjan, Selo.1994.Culture, Development\&Democracy.Tokyo:The United Nations University Press

[10] Rif'an, Ali.(2010).Buku Pintar Wayang. Jogjakarta:Garailmu

[11] Darmojo, H \& Jenny R.E. Kaligis.(1993). Pendidikan IPA 2. Depdikbud: Yogyakarta Prastowo, Andi.(2011). Panduan Kreatif Membuat Bahan Ajar Inovatif.Yogyakarta: Divapress

[12] Ki Sumanto Susilomadya. (2014).Mari Mengenal Wayang.Yogyakarta:adiwacana

[13] Borg, W. R. \& Gall, M. D. “Educational research: An introduction (4thed).” New York: Longman, Inc. (1983). 
[14] Kern, Richard.2014. Language, Teaching and Literacy.University of California, Berkeley. Publisher: Cambridge University Press; Online

[15] data kepariwisataan.go.id, retrieved on July 2016.

[16] Puspita Sari, Dian.(2015). Pengembangan LKS Tematik Materi Jenis - jenis Pekerjaan untuk Kelas IV MI/SD. SKRIPSI UINi. 